
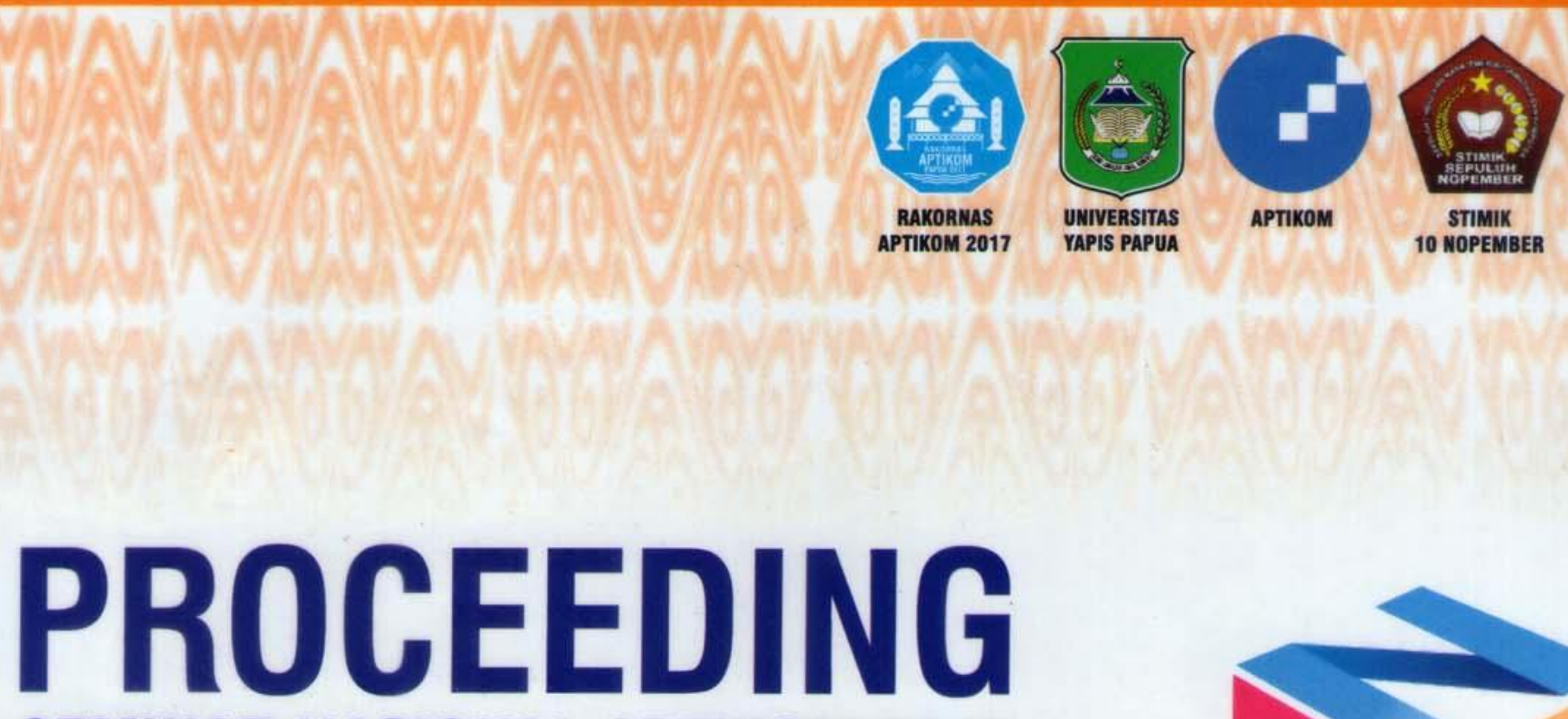
SEMINAR NASIONAL APTIKOM 2017

Jayapura, 3 November 2017

Peningkatan Kompetensi SDM TIK dan Daya Saing Daerah di Era Global
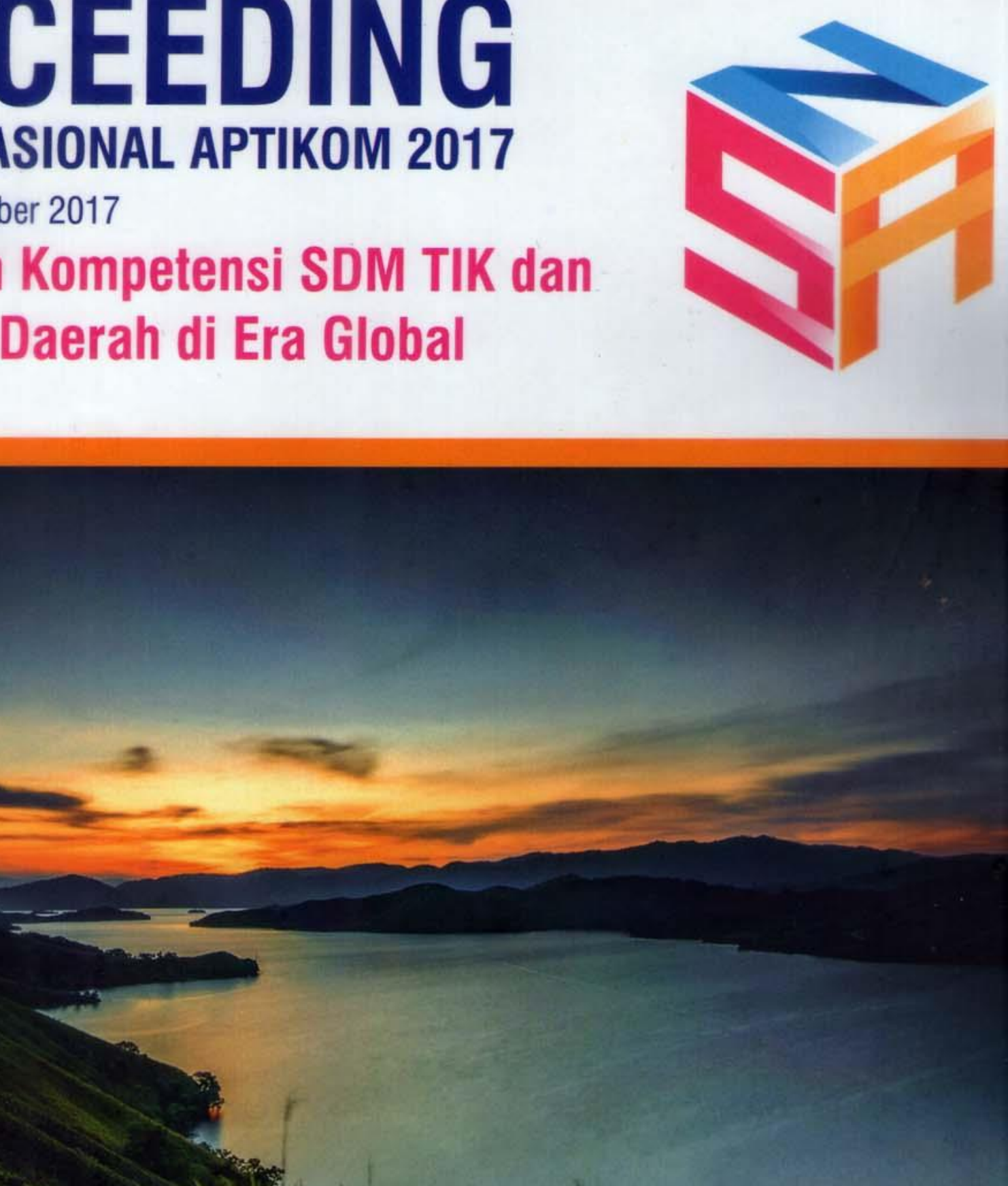


\section{Proceeding Book}

\section{Seminar Nasional APTIKOM 2017 \\ Peningkatan Kompetensi SDM TIK dan Daya Saing Daerah di Era Global}

ISBN: 978-602-50434-0-6

\section{Ketua Editor}

Mursalim Tonggiroh, S.Kom., M.Eng

\section{Sekretaris Editor}

Evanita Veronica Manullang, MT.

\section{Anggota Editor}

Abd. Rahman Dayat, S.Kom., M.Kom

Jusmawati, S.Kom., M.Kom

Penerbit dan Redaksi:

Universitas Yapis Papua

Jalan DR. Sam Ratulangi No.11 Dok V Atas Jayapura, Papua

Telp: (0967) 534012; Fax: (0967) 537985

Email: semnastikom2017@gmail.com

Dicetak oleh:

CV. Sagita Grafika

Jalan DR. Sam Ratulangi No.3 Jayapura, Papua

Telp: (0967) 531766

Email: sagitagrafika@gmail.com

Cetakan Pertama, Oktober 2017

Hak cipta dilindungi undang-undang

Dilarang memperbanyak karya tulis ini dalam bentuk dan dengan cara apapun tanpa ijin tertulis dari penerbit. 


\section{STEERING COMMITTEE}

Prof. Ir. Zainal A. Hasibuan, MLS., Ph.D. (Ketua APTIKOM)

Prof. Dr. Achmad Benny Mutiara Q. N. (Wakil Ketua APTIKOM)

Dr. H. Muhdi B. Hi. Ibrahim, SE., MM (Rektor Universitas Yapis Papua)

Dr. Rosiyati M. H. Thamrin, SE., MM (Ketua STIMIK Sepuluh Nopember Jayapura)

\section{REVIEWER}

Prof. Ir. Zainal A. Hasibuan, MLS., Ph.D. (Universitas Indonesia)

Dr. Prihandoko, MIT (Universitas Gunadarma)

Dr. Dwiza Riana, S.Si, MM, M.Kom (STMIK Nusa Mandiri)

Dr. Asep Sholahuddin, MT. (Universitas Padjadjaran)

Dr.rer.nat. Cecilia Esti Nugraheni, S.T., M.T. (Universitas Parahyangan Bandung)

Dr. Ir. Noor Cholis Basjaruddin, MT (Politeknik Negeri Bandung)

Dr. Bayu Erfianto, S.Si., MSc. (Telkom University)

Dr. Shelvie Nidya Neyman, S.Kom., M.Si (Institut Pertanian Bogor)

Dr. Nina Kurnia Hikmawati, SE., MM. (Telkom University)

Dr. Rani Megasari, S.Kom., M.T. (Universitas Pendidikan Indonesia)

Dr. Yus Sholva, ST., MT. (Universitas Tanjungpura)

Dr. Mochamad Wahyudi, MM., M.Kom, M.Pd (STMIK Nusa Mandiri)

Muh. Qomarul Huda, Ph.D (UIN Syarif Hidayatullah Jakarta)

Dr. Titin Pramiyati,S.Kom., M.Si (UPN Veteran Jakarta)

Dr. Khusnul Khotimah, M.Si (Universitas Yapis Papua)

\section{TECHNICAL COMMITTEE}

Mursalim Tonggiroh, S.Kom., M.Eng

Evanita Veronica Manullang, MT.

Abd. Rahman Dayat, S.Kom., M.Kom

Jusmawati, S.Kom., M.Kom 


\section{DAFTAR ISI}

\begin{tabular}{|c|c|c|c|}
\hline $\begin{array}{l}\text { Kode } \\
\text { Paper }\end{array}$ & $\begin{array}{c}\text { Judul } \\
\text { (Penulis) }\end{array}$ & Institusi & Halaman \\
\hline BD-1 & $\begin{array}{l}\text { Model Arsitektur Infrastruktur Dan Aplikasi Manajemen Operasional Big } \\
\text { Data Untuk UMKM } \\
\text { (Gede Karya, Veronica S. Moertini) }\end{array}$ & $\begin{array}{l}\text { Universitas } \\
\text { Katolik } \\
\text { Parahyangan }\end{array}$ & $1-6$ \\
\hline $\mathrm{CC}-1$ & $\begin{array}{l}\text { Aplikasi Digital Library Dengan Infrastruktur Cloud Computing } \\
\text { (Ina Agustina, Andrianingsih, Haromen) }\end{array}$ & $\begin{array}{l}\text { Universitas } \\
\text { Nasional Jakarta }\end{array}$ & $7-11$ \\
\hline CG-1 & $\begin{array}{l}\text { Sistem Pendeteksi Pola Tajwid Al-Qur'an Hukum Mad Thabi'l } \\
\text { Menggunakan Metode Sokal \& Michener } \\
\text { (Bustami, Fadlisyah, Dian Siddiq) }\end{array}$ & $\begin{array}{l}\text { Universitas } \\
\text { Malikussaleh }\end{array}$ & $12-17$ \\
\hline CRM-1 & $\begin{array}{l}\text { Technology Acceptance Model Untuk Menganalisa Kepuasan } \\
\text { Pengguna Aplikasi E-Smart } \\
\text { (Syam Gunawan, Rika Siti Syarifah) }\end{array}$ & STMIK Indonesia & $18-24$ \\
\hline CRM-2 & $\begin{array}{l}\text { Evaluasi Pengaruh Kualitas Pelayanan Situs terhadap Masukan Kritik } \\
\text { dan Saran Kepuasan Pengguna } \\
\text { (Agus Dendi Rachmatsyah, Harrizki Arie Pradana) }\end{array}$ & $\begin{array}{l}\text { STMIK Atma } \\
\text { Luhur } \\
\text { Pangkalpinang }\end{array}$ & $25-32$ \\
\hline CRM-3 & $\begin{array}{l}\text { Pengukuran Pengaruh Pemanfaatan Teknologi Informasi Terhadap } \\
\text { Kinerja Individual } \\
\text { (Teguh Priyantoro) }\end{array}$ & $\begin{array}{l}\text { STMIK Agamua } \\
\text { Wamena }\end{array}$ & $33-36$ \\
\hline CRM-4 & $\begin{array}{l}\text { Aplikasi Amos dalam Analisis Peran Human Capital dalam } \\
\text { Meningkatkan Harga Saham Perbankan } \\
\text { (Yana Ermawati, Muhamad.Yamin Noch, Zakaria) }\end{array}$ & $\begin{array}{l}\text { Universitas Yapis } \\
\quad \text { Papua }\end{array}$ & $37-43$ \\
\hline CRM-5 & $\begin{array}{l}\text { Analisis Technology Acceptance Model Terhadap Penerapan E- } \\
\text { Commerce Pada UKM Kota Jayapura } \\
\text { (Septyana Prasetianingrum, Fajar Rina Sejati) }\end{array}$ & $\begin{array}{c}\text { Universitas Yapis } \\
\text { Papua }\end{array}$ & $44-49$ \\
\hline CRM-6 & $\begin{array}{l}\text { Analisis Sistem Informasi Geografis Pariwisata Propinsi Papua } \\
\text { (Ari Widiastono, Liza Angriani) }\end{array}$ & $\begin{array}{l}\text { AMIK Umel } \\
\text { Mandiri }\end{array}$ & $50-54$ \\
\hline CS-1 & $\begin{array}{l}\text { Korelasi Tingkat Kesalahan dan Epoh Dalam Jaringan Backpropagation } \\
\text { (Hindayati Mustafidah, Harjono) }\end{array}$ & $\begin{array}{l}\text { Universitas } \\
\text { Muhammadiyah } \\
\text { Purwokerto }\end{array}$ & $55-61$ \\
\hline CS-2 & $\begin{array}{l}\text { Analisis Perbandingan Implementasi Kernel Pada Library LibSVM } \\
\text { Untuk Klasifikasi Sentimen Menggunakan Weka } \\
\text { (Prawidya Destarianto, Wahyu Kurnia Dewanto, Hermawan Arief } \\
\text { Putranto) }\end{array}$ & $\begin{array}{l}\text { Politeknik Negeri } \\
\text { Jember }\end{array}$ & $62-66$ \\
\hline$C V-1$ & $\begin{array}{l}\text { Penerapan Algoritma Muliple Flow Direction Untuk Pemodelan } \\
\text { Genangan Banjir } \\
\text { (Mohamad Arif Suryawan, Ery Muchyar Hasiri) }\end{array}$ & $\begin{array}{l}\text { Universitas } \\
\text { Dayanu } \\
\text { Ikhsanuddin } \\
\end{array}$ & $67-70$ \\
\hline CV-2 & $\begin{array}{l}\text { Aplikasi Pengenalan Plat Nomor Kendaraan Bermotor Menggunakan } \\
\text { Metode Learning Vector Quantization } \\
\text { (Hamsina, Evanita V Manullang) }\end{array}$ & $\begin{array}{l}\text { Universitas Sains } \\
\text { dan Teknologi } \\
\text { Jayapura }\end{array}$ & $71-76$ \\
\hline DBM-1 & $\begin{array}{l}\text { Optimasi Query Untuk Pencarian Data Menggunakan Penguraian } \\
\text { Kalimat Dan Algoritme Levenshtein Distance } \\
\text { (M. El Bahar Conoras, Aprian Dwi Kurnawan) }\end{array}$ & $\begin{array}{l}\text { Universitas } \\
\text { AMIKOM } \\
\text { Yogyakarta } \\
\end{array}$ & $77-81$ \\
\hline DBM-2 & $\begin{array}{l}\text { Implementasi Teknik Replikasi Database Terdistribusi Pada Toko } \\
\text { Online Deltaphone Jayapura } \\
\text { (Mirsan Irianto, Marla Sheilamita Shalin Pieter) }\end{array}$ & $\begin{array}{l}\text { Universitas Sains } \\
\text { dan Teknologi } \\
\text { Jayapura }\end{array}$ & $82-87$ \\
\hline
\end{tabular}




\title{
PENERAPAN ALGORITMA MULTIPLE FLOW DIRECTION UNTUK PEMODELAN GENANGAN BANJIR
}

\author{
Mohamad Arif Suryawan ${ }^{1}$, Ery Muchyar Hasiri ${ }^{2}$ \\ 1,2Teknik Informatika, Fakultas Teknik, Universitas Dayanu Ikhsanuddin \\ Jl. Dayanu Ikhsanuddin no.124 Baubau, Sulawesi Tenggara \\ 1arwan97@yahoo.com, ${ }^{2}$ erymuchyar82@gmail.com
}

\begin{abstract}
Abstrak
Genangan air sering kali terjadi pada daerah rendah karena volume air hujan yang besar. Genangan air dalam jumlah besar dapat mengakibatkan banjir, oleh karena itu diperlukan simulasi genangan air dengan bantuan aplikasi komputer. Penelitian ini bertujuan untuk mengetahui genangan banjir yang terjadi berdasarkan titik-titik ketinggian piksel pada peta Digital Elevation Model (DEM), titik-titik ketinggian piksel mewakili ketinggian permukaan tanah. Algoritma Multiple Flow Direction (MFD) digunakan untuk mengetahui arah dan genangan air yang mungkin terjadi pada daerah rendah. Penelitian ini merupakan perancangan sistem dalam bentuk pemodelan yang diawali dengan perumusan masalah, studi kepustakaan dan penelitian ekperimental dengan mengembangkan algoritma MFD untuk menentukan arah aliran air. Air akan mengalir ke seluruh area piksel disekelilingnya yang memiliki nilai piksel yang lebih rendah dari piksel awal. Hasil penelitian ini menunjukkan daerah genangan banjir yang terjadi dari beberapa sumber titik awal air mengalir.
\end{abstract}

Kata Kunci : DEM, multiple flow direction, genangan banjir.

\section{Pendahuluan}

Genangan air yang sering terjadi pada daerah rendah pada musin hujan sering menjadi bencana yang berbahaya jika volume airnya sangat besar. Volume air yang besar pada saat hujan dapat berakibat bencana banjir. Hal ini diakibatkan saluran air yang kurang baik atau daya tampung saluran air yang melebihi kapasitasnya. Oleh karena itu di perlukan tindakan untuk mengatasi permasalahan banjir. Tindakan awal yang dapat dilakukan adalah mengantisipasi sebelum terjadi banjir dengan simulasi.

Simulasi genangan air dapat memodelkan aliran dan genangan air permukaan pada peta yang memiliki data Digital Elevation Model (DEM). Data DEM adalah titik-titik piksel yang merupakan salah satu data spasial yang memiliki informasi ketinggian permukaan tanah. Semakin tinggi resolusi peta DEM yang digunakan dalam simulasi akan semakin akurat hasil yang didapatkan. Ada beberapa algoritma yang digunakan untuk memodelkan aliran air permukaan, salah satu algoritma tersebut adalah Multiple Flow Direction (MFD).

Algoritma MFD dapat memodelkan aliran air dalam piksel-piksel peta DEM karena algoritma tersebut dapat menentukan pergerakan titik-titik piksel ke semua arah yang memiliki piksel yang lebih rendah dari piksel awal, sehingga dapat digunakan untuk mensimulasikan aliran air dari beberapa sumber air. Oleh karena itu, penelitian ini bertujuan untuk membuat program aplikasi yang dapat memodelkan genangan banjir yang terjadi berdasarkan titik-titik ketinggian piksel pada peta
DEM, titik-titik ketinggian piksel tersebut mewakili ketinggian permukaan tanah.

\section{Tinjauan Pustaka}

\subsection{Simulasi Banjir}

Simulasi banjir diperlukan sebagai bagian dari sistem informasi dan peringatan dini bencana banjir [9]. Sistem perangkat lunak simulasi banjir tersebut dapat menghasilkan simulasi terjadinya genangan air yang mungkin dapat mengakibatkan banjir.

Simulasi merupakan pemodelan yang dilakukan dengan bantuan aplikasi komputer dengan tujuan untuk mengetahui dan memprediksi yang mungkin dapat terjadi pada keadaan sebenarnya di lapangan. Simulasi genangan air dengan media peta DEM untuk antisipasi peringatan bencana banjir dapat mengetahui progres terjadinya genangan air yang mungkin terjadi pada suatu daerah [6].

Peringatan dini bencana banjir dapat disimulasikan di atas permukaan peta DEM dan konsep aliran air dengan cellular automata. Cellular automata memodelkan aliran air sehingga membentuk genangan banjir dengan parameter volume air dan daya serap [3].

Simulasi dengan menggunakan peta DEM merepresentasikan data elevasi digital. Data elevasi digital yang terdapat dalam datasets DEM mungkin saja terdapat kesalahan. Kesalahan tersebut bisa disebabkan usia data, kepadatan daerah pengamatan yang dapat menyebabkan kesalahan pengamatan [7]. Oleh karena itu data DEM dengan resolusi yang 
tinggi sangat dibutuhkan untuk menghasikan simulasi yang akurat.

\subsection{Digital Elevation Model (DEM)}

Data DEM didapat dari hasil penginderaan jauh seperti foto satelit, salah satu foto satelit yang dapat memberikan informasi DEM adalah cartosat-1 karena memiliki resolusi gambar yang tinggi. DEM yang dihasilkan divalidasi menggunakan titik kontrol tanah yang digunakan untuk mengevaluasi parameter permukaan tanah seperti ketinggian, kemiringan, kontur, pola drainase, dan tematik peta geologi dan geomorfologi penggunaan lahan dan peta tanah. Ketepatan DEM pada gambar satelit cartosat-1 dengan titik kontrol tanah berkisar pada 0,5 meter sehingga cartosat-1 baik digunakan untuk mengetahui ketinggian permukaan tanah [5].

Ketepatan model simulasi tidak hanya tergantung akurasi data DEM, tetapi bergantung pada struktur model hidrologi dan hidrolik. Model hidrologi hanya membutuhkan aliran air permukaan yang menjadi pertimbangan dan proses hidrolik disederhanakan. Persamaan kontinuitas terkait aliran masuk atau keluar dari piksel data DEM dan perubahan dalam volume air, persamaan momentum untuk setiap arah dihitung menurut rumus Manning, simulasi yang dihasilkan tidak selalu sama dengan kenyataannya di lapangan, oleh karena itu dibutuhkan analisis lebih lanjut tentang akurasi dari ketidakpastian simulasi genangan banjir lebih detail, utamanya pengumpulan data alur sungai dan melakukan pengamatan banjir [10].

\subsection{Mutiple Flow Direction (MFD)}

Algoritma Multiple Flow Direction (MFD) adalah algoritma yang menentukan arah aliran lebih dari satu piksel yang memiliki nilai terendah dibanding dengan titik awal. Perpindahan aliran pada algoritma ini dimodelkan dengan perpindahan status suatu sel yang berisi air menuju beberapa sel tetangganya yang memiliki nilai lebih rendah di sekelilingnya. Ilustrasi aliran air dengan Algoritma Multiple Flow Direction (MFD) terdiri dari tiga titik awal yaitu A,B dan C menuju titik-titik piksel yang lebih rendah, seperti terlihat pada gambar 1 berikut ini :

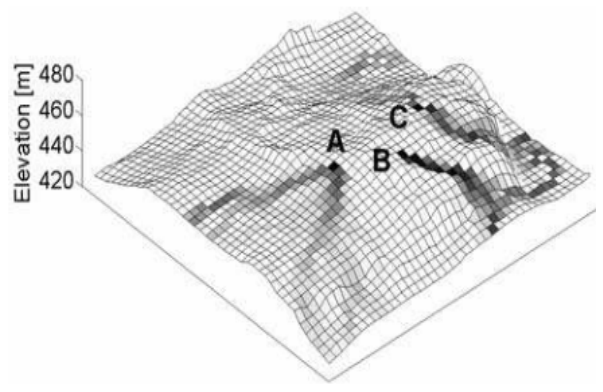

Gambar 1. Multiple Flow Direction dari tiga piksel tinjauan [4].
Konsep aliran air menggunakan algoritma MFD dapat membentuk genangan banjir berdasarkan parameter yang digunakan adalah curah hujan, serapan tanah, dan durasi hujan. Parameter tersebut sangat berpengaruh pada luas genangan banjir yang akan terjadi [8].

Parameter volume air per satuan waktu dalam simulasi genangan banjir berdasarkan data DEM. Peta yang memiliki data DEM harus menggunakan resolusi yang tinggi dengan metode ring sehingga membentuk genangan banjir. Metode ring membentuk lingkaran genangan, genangan akan berhenti pada titik maksimum [1].

Algoritma MFD sebagai penentu arah aliran air berdasarkan titik-titik elevasi peta DEM dijadikan sebagai algoritma dasar, kemudian algoritma Depth First Search (DFS) digunakan untuk menentukan tujuan air yang akan mengalir mengikuti ketinggian piksel sampai pada titik terendah [2]. Simulasi genangan banjir yang dihasilkan perlu dilakukan pembuktian dengan data-data yang ada dilapangan.

Titik-titik ketinggian (elevasi) pada peta DEM mengalirkan air pada titik yang ada disekelilingnya dan berhenti pada titik elevasi terendah sampai terjadi genangan air seperti terlihat pada gambar 2 .

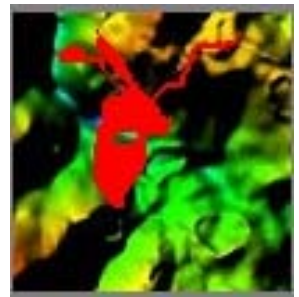

Gambar 2. Aliran yang membentuk genangan air dengan algoritma MFD

Daerah genangan air terlihat (gambar 2) berwarna merah menunjukkan daerah tergenang yang memiliki elevasi rendah. Titik sumber air akan menyebar pada titik elevasi terendah yang ada pada delapan titik piksel disekelilingnya, pola penyebaran air diilustrasikan pada gambar 3 di bawah ini :

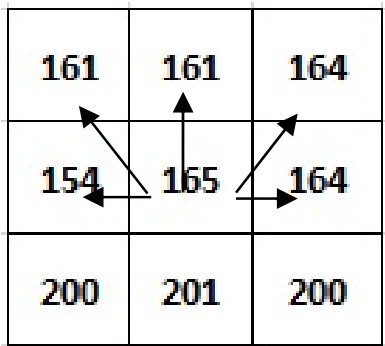

Gambar 3. Arah aliran air pada algoritma MFD

Titik piksel awal (165) akan mengalir menuju piksel yang lebih rendah yaitu piksel 154, 161, dan 164. Tiga titik yang lebih rendah tersebut (154, 161, dan 164) menjadi titik awal untuk menentukan arah aliran air berikutnya sampai tidak ditemukan lagi titik-titik piksel yang lebih rendah. 
3. Metodologi

Penelitian yang dilakukan digambarkan dengan desain sistem sebagai berikut :

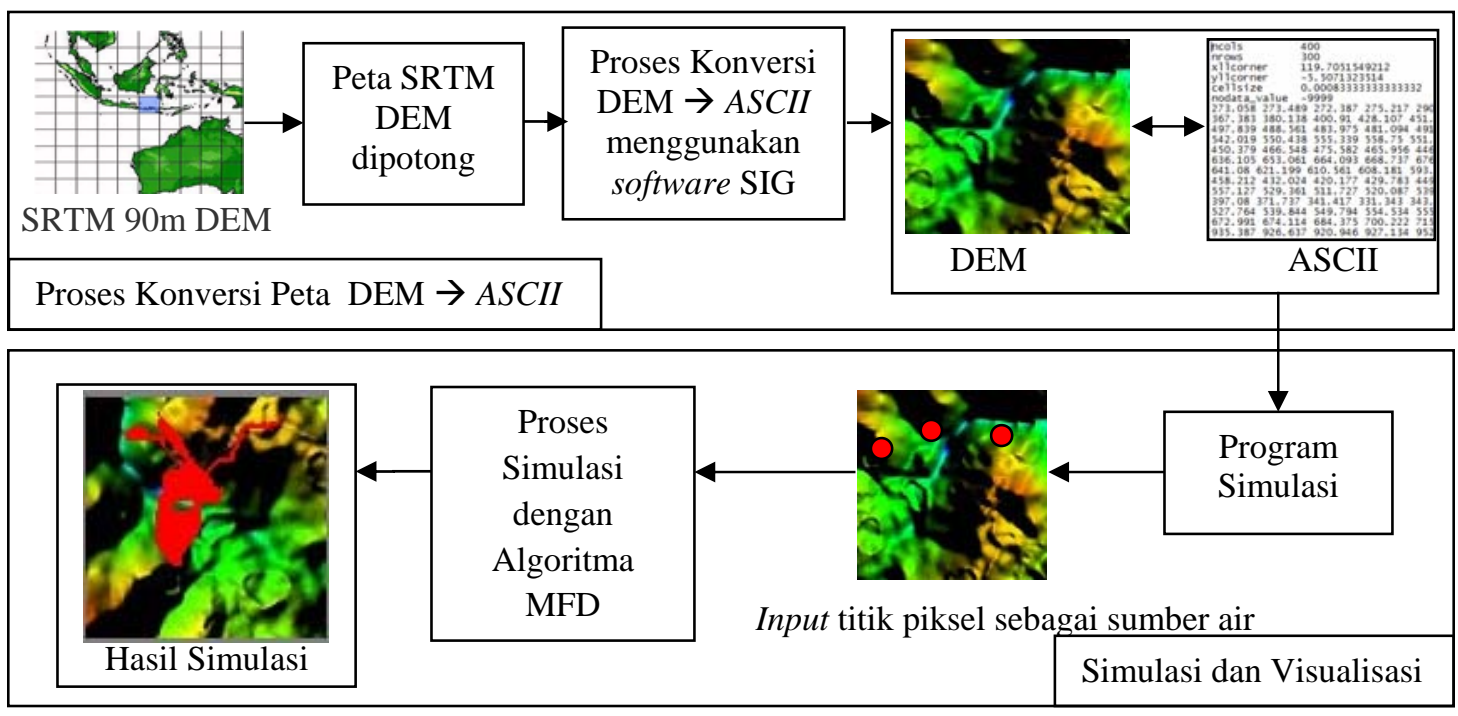

Gambar 4. Diagram desain sistem

Desain sistem pada gambar 4, ada dua proses utama yang dikembangkan dalam sistem yang di bangun yaitu :

1. Proses konversi peta DEM ke dalam data ASCII. Proses ini menggunakan software Sistem Informasi Geografis (SIG), mulai dari pemotongan peta SRTM 90m DEM version 4 sampai pada proses konversi peta DEM sehingga memiliki data ASCII. Data ASCII adalah angka-angka yang merupakan titik-titik elevasi (ketinggian tanah) dari peta DEM. Titiktitik elevasi tersebut akan digunakan untuk proses simulasi.

2. Simulasi dan visualisasi. Simulasi dimulai dengan melakukan input koordinat piksel, volume air dan daya serap. Kemudian sistem akan melakukan proses simulasi dengan algoritma MFD. Algoritma MFD merupakan algoritma yang akan membantu sistem menentukan genangan air, air akan mengalir dari titik koordinat piksel dari yang tinggi ke rendah. Simulasi yang dihasilkan adalah gambar genangan air yang terbentuk dari piksel-piksel yang memiliki nilai elevasi terendah yang berada di sekitar titik awal air.

\section{Hasil dan Pembahasan}

Percobaan dilakukan dengan masukkan tiga titik piksel awal. Koordinat titik pertama adalah $(30,6)$ dengan ketinggian 436, titik kedua $(16,15)$ dengan ketinggian 389 dan titik ketiga $(81,7)$ dengan ketinggian 408. Hasil yang didapatkan terlihat pada gambar 5. Pada gambar tersebut terdiri dari lima gambar peta yang memperlihatkan aliran air dari titik pertama, kedua dan ketiga, sampai terbentuk sebuah genangan banjir (warna merah).

Progress dari test simulasi yang dilakukan menunjukkan bahwa air mengalir dari tiga titik koordinat. Dari gambar 5 di bawah, terlihat bahwa gambar peta 1 menunjukkan aliran air dari titik koordinat satu, menggenangi daerah piksel disekitarnya yang rendah, kemudian pada gambar peta 2, air mulai mengalir dari titik piksel kedua dan menggenangi piksel sekitarnya yang rendah, selanjutnya pada gambar peta 3 , air mulai mengalir dari titik piksel ketiga mengalir ke piksel yang lebih rendah sampai membentuk area genangan air. Pada gambar peta 5, air telah menggenangi semua titiktitik piksel yang rendah dan membentuk genangan.

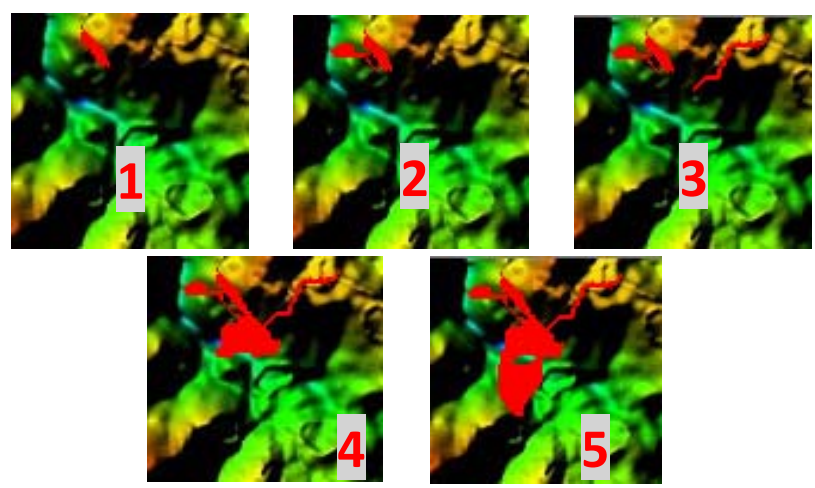

Gambar 5. Progres aliran dan genangan air menggunakan program simulasi 


\section{Kesimpulan}

Kesimpulan yang dapat diambil dari penelitian yang telah dilakukan adalah :

1. Algoritma MFD dapat digunakan untuk mengetahui arah aliran yang membentuk genangan banjir berdasarkan titik-titik piksel elevasi pada peta DEM.

2. Terjadinya genangan air pada peta DEM daerah tinjauan berdasarkan titik awal sumber air yang mengalir mengikuti titik-titik piksel yang memiliki elevasi rendah disekitarnya, genangan akan berhenti bila semua titik-titik piksel terendah telah terisi air.

\section{Daftar Pustaka:}

[1] Hai, Sun., Cheng, Wang \& Bo, Ren., 2008, Method of DEM Data's Processing in Flood Simulation System. Internatio Conference on Computer Science and Software Engineering, IEEE.

[2] Paulus, Yesaya Tommy, 2012, Simulasi Arah Aliran Air Permukaan Menggunakan Algoritma Depth First Search dengan Sumber Air Multipoint, Tesis, Makassar: Teknik Elektro Universitas Hasanuddin.

[3] Rasyid, Nurhasanah, 2011, Simulasi Aliran dan Distribusi Air Permukaan Menggunakan Model Elevasi Digital dan Cellular Automata dengan Memperhitungkan Volume dan Daya Serap, Tesis, Makassar: Teknik Elektro Universitas Hasanuddin.
[4] Seibert, J. \& McGlynn, Brian L., 2007, A new triangular multiple flow direction algorithm for computing upslope areas from gridded digital elevation models, Water Resources Research, VOL. 43, W04501.

[5] Suganthi, S. \& Srinivasan, K., 2010, Digital Elevation Model Generation and Its Application in Landslide Studies Useing Cortosat-1, International Journal of Geomatic and Geoscience, Volume 1, No.1.

[6] Suryawan, M. Arif, 2015, Simulasi Genangan Air untuk Antisipasi Peringatan Dini Bencana Banjir, Tesis, Makassar: Pasca Sarjana Teknik Elektro Universitas Hasanuddin.

[7] Susanne, P.W., 2003, Perception of Digital Elevation Model Uncertainty by DEM Users. URISA Journal.

[8] Wati, Masna, 2012, Simulasi Aliran Permukaan dengan Kecepatan Aliran Air Menggunakan Persamaan Benoulli, Tesis, Makassar: Teknik Elektro Universitas Hasanuddin.

[9] Zainuddin, Zahir dkk., 2012, Integrasi Sistem Informasi Jaringan Sensor Hidrologi Nirkabel dan Model Hidrodinamik berbasis GIS untuk Peringatan Dini Bencana Banjir, Prosiding InSINas. 0927:TI50-TI54.

[10] Zheng, N., Tachikawa, Y., \& Takara, K., 2008, A Distribute Flood Inundation Model Integrating with Rainfall-Runoff Processes Using GIS and Remote Sensing Data, The International Archives of Photogrametry, Remote Sensing and Spatial Information Science, vol.XXXVII, part.B4. 